\title{
Identifikasi Citra Jenis Bunga menggunakan Algoritma KNN dengan Ekstrasi Warna HSV dan Tekstur GLCM
}

\author{
Alifa Puteri Bilqis Salsabila ${ }^{1}$ \\ Rika Desma Yunita ${ }^{2}$ \\ Chaerur Rozikin ${ }^{3}$
}

Program Studi Teknik Informatika, Universitas Singaperbangsa Karawang ${ }^{1,2,3}$

Jln. HS. Ronggo Waluyo, Puseurjaya, Kec. Telukjambe Timur, Kabupaten Karawang ${ }^{1,2,3}$

\section{E-mail: alifa.salsabila17047@student.unsika.ac.id ; rika.yunita17180@student.unsika.ac.id²; chaerur.rozikin@staff.unsika.ac.id²}

Salsabila, A., Yunita, R. ., \& Rozikin, C. (2021). Identifikasi Citra Jenis Bunga menggunakan Warna HSV dan Tekstur GLCM . Technomedia Journal, 6(1 Agustus).

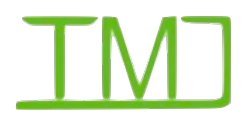

https://doi.org/10.33050/tmj.v6i1 Agustus.1667

\begin{abstract}
ABSTRAK
Beragamnya jenis bunga yang ada serta memiliki spesies dan kemiripan pada setiap ragamnya, membuat para pecinta tanaman dan pembudi daya sulit untuk membedakan dalam penentuan jenis bunga, diperlukannya waktu yang sangat lama untuk mengetahui jenis bunga jika hanya mengandalkan panca indera saja. Penerapan algoritma K-Nearest Neighbor serta ekstrasi ciri terhadap warna dan tekstur sangat membantu dalam pengolahan citra untuk mengidentifikasi bunga menjadi lebih mudah dan mempersingkat waktu, dengan akurasi terbesar 71\% menggunakan nilai K-7, identifikasi bunga berhasil dilakukan.
\end{abstract}

Kata kunci : Identifikasi, Warna HSV, Tekstur GLCM, K-Nearest Neighbor

\section{ABSTRACT}

Due to the variety of types of flowers that exist and having and tracking each variety, making plant lovers and cultivators difficult to distinguish in determining the type of flower, it takes a very long time to find out the type of flower if you only rely on the five senses. With the application of the K-Nearest Neighbor algorithm and feature extraction of color and texture, it is very helpful in image processing to identify flowers more easily and shorten the time, with the greatest accuracy of $71 \%$ using the K-7 value, the flower was successfully carried out.

Keywords: Identification, HSV, GLCM, K-Nearest Neighbor

\section{PENDAHULUAN}

Bunga terdiri dari daun dan ranting yang ada di sekitarnya serta telah terjadi banyak perubahan. Perubahan ini dikarenakan oleh hasil dari sejumlah enzim yang dirangsang oleh sejumlah fitohormon tertentu [1]. Terbentuknya sebuah bunga sangat ketat dikendalikan secara genetik dan banyak jenis diinduksi pada perubahan lingkungan tertentu, seperti rendahnya suhu, kurang pencahayaan dari sinar matahari, dan air yang ada. Bunga hampir selalu berbentuk sama sisi, hal tersebut sering digunakan sebagai ciri dari sebuah takson. Ada dua bentuk bunga berdasar simetri bentuknya: aktinomorf dan zigomorf. Bentuk aktinomorf sangat mudah untuk ditemukan [2]. Dengan keindahan yang ada pada bunga tersebut mengakibatkan 
pecinta tanaman dan pembudi daya semakin banyak serta produksi bunga terus bertumbuh dan berkembang [3].

Maka dari itu teknologi komputer berkembang pesat sebagai alat untuk mendapatkan informasi yang bisa digunakan untuk mengetahui jenis-jenis bunga [4]. Komputer dapat mengolah data secara cepat, tepat dan akurat dengan tingkat ketelitian yang tinggi, sehingga dapat menjadi alat untuk mendapatkan informasi yang dibutuhkan sesuai dengan kebutuhan manusia di berbagai bidang [5]. Perkembangan pada teknologi pengolahan citra sekarang ini menyediakan kemungkinan manusia untuk membuat suatu sistem yang dapat mengenali sesuatu pada citra digital [6]. Pengolahan citra juga merupakan salah satu jenis teknologi untuk menyelesaikan masalah mengenai pengolahan gambar [7]. Dalam pengolahan citra, gambar diolah sedemikian rupa sehingga gambar tersebut dapat digunakan untuk aplikasi lebih lanjut [8]. Oleh karena itu, tuntutan informasi mengenai jenis-jenis bunga mendorong terciptanya sistem untuk mengidentifikasi dengan basis pengolahan citra digital. Seperti pada penelitian sebelumnya yang menggabungkan antara pengolahan citra digital dengan kecerdasan buatan untuk menghasilkan pengenalan absensi wajah di sekolah Shafiyyatul Amaliyyah menggunakan klasifikasi metode K-NN , penelitian selanjutnya adalah percobaan dan analisis hasil pengujian metode klasifikasi ikan dengan menggunakan ORB dan K-NN, pada penelitian selanjutnya ialah deteksi bakteri pada pandemic covid berdasarkan warna HSV adapula penelitian yang membahas pendeteksian batik dengan ekstrasi tekstur penelitian terakhir ialah menggunakan algoritma KNN sebagai klasifikasi penyakit ginjal kronis , berdasarkan penelitian-penelitian sebelumnya peneliti mendapatkan ide untuk melakukan identifikasi terhadap bunga dikarenakan pecinta tanaman dan budi daya tanaman sangat banyak

\section{PERMASALAHAN}

Permasalah yang ada berdasarkan produksi tanaman hias yang melonjak pada tahun 2019 menjadikan para pecinta tanaman terus bertambah dan untuk meminimalisir permasalahan ketidak tahuan terhadap jenis-jenis bunga yang ada, maka dari itu perlu dibuatkannya sebuah sistem yang membantu untuk mengidentifikasi jenis bunga.

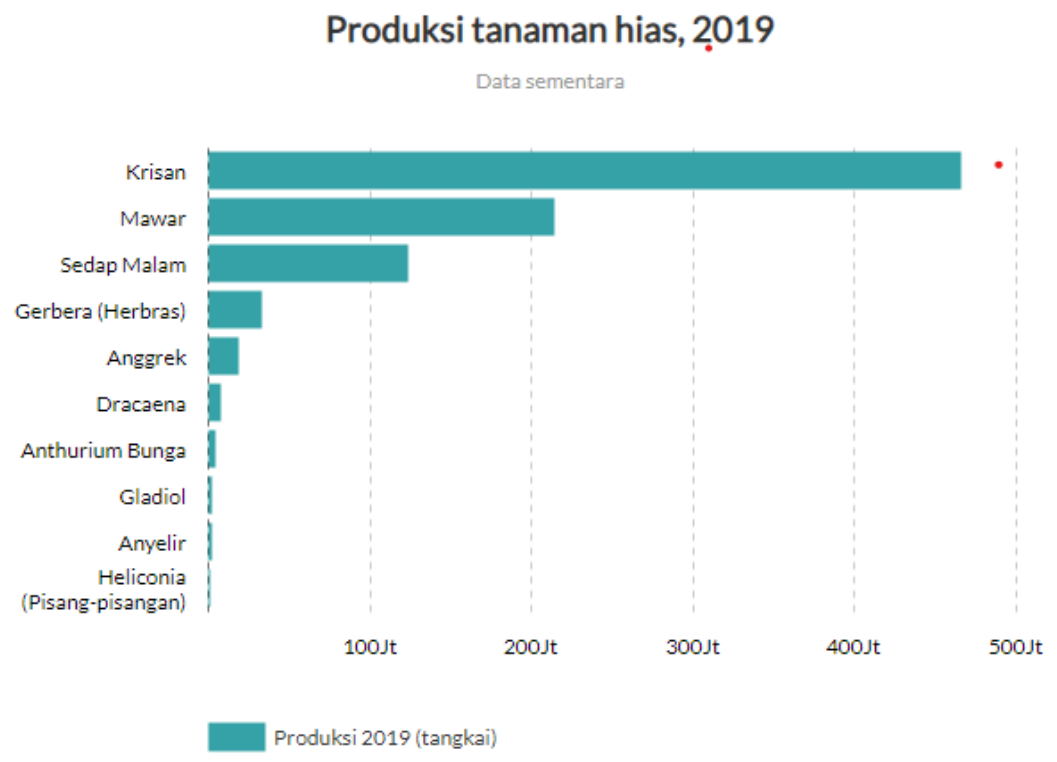

Gambar 1. Produksi Tanaman Hias 2019

(Sumber : Kementrian Pertanian) 


\section{METODOLOGI PENELITIAN}

Metodologi penelitian ini berdasarkan pada tahapan pengolahan citra digital.

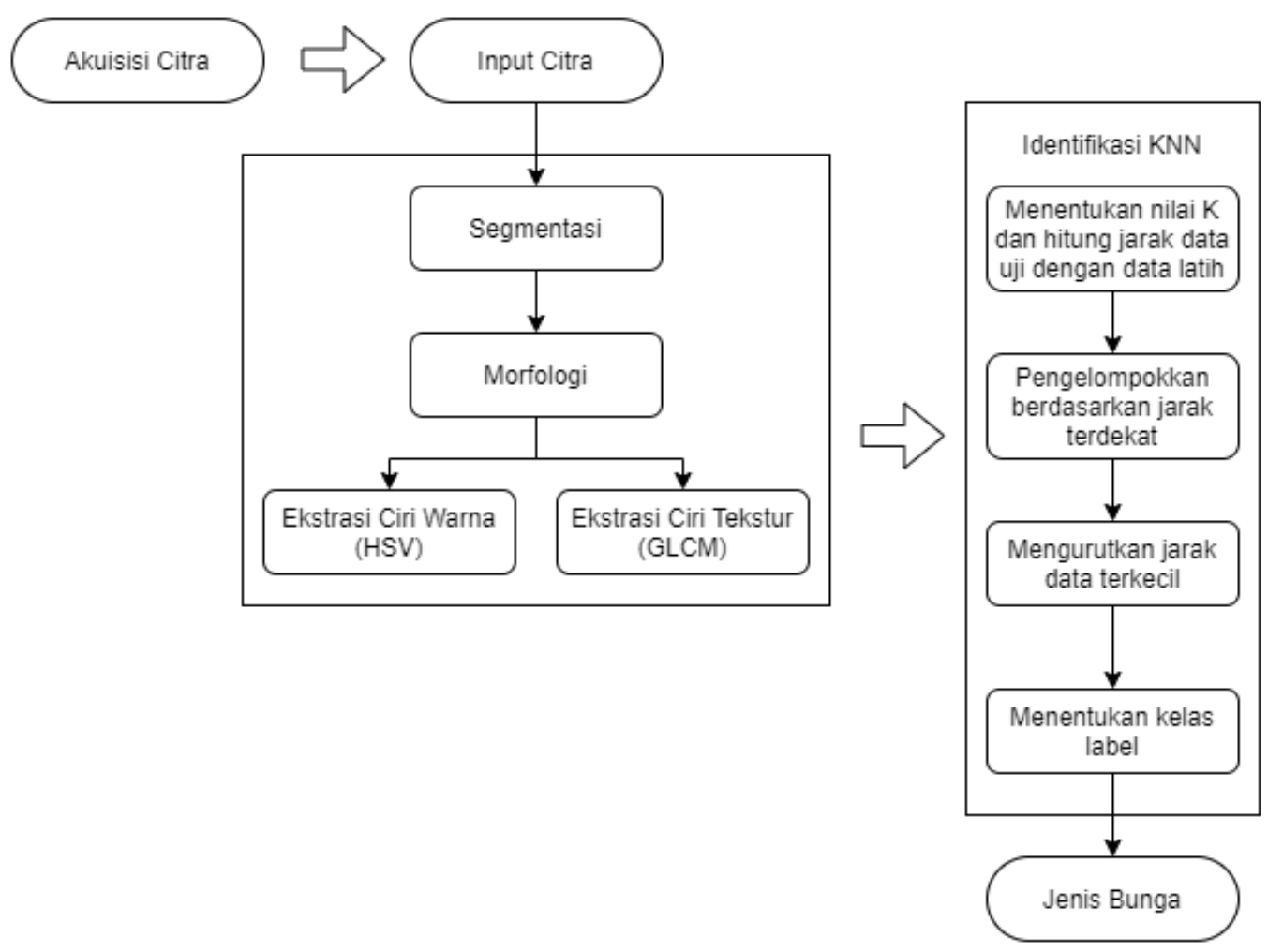

Gambar 2. Alur Penelitian

1. Pengumpulan data : Tujuan pada tahap ini ialah untuk menentukan data yang dibutuhkan dan pemilihan metode pengolahan citra digital [9]. Langkah-langkah yang dilakukan dalam ini secara umum dimulai dari persiapan objek yang akan diambil citranya, sampai proses pencitraan [10]. Pada proses ini pengambilan citra dilakukan di https://www.kaggle.com/ dengan judul Flower Color Image data citra akan digunakan sebagai sampel untuk identifikasi berdasarkan warna dan tekstur pada jenis bunga. Data citra hanya menggunakan 10 jenis bunga [11].

2. Pre Processing: Proses pre processing digunakan untuk memperoleh citra yang akan dilanjutkan dan dimanfaatkan untuk sistem yang dirancang. Proses ini terdiri dari proses cropping, resize, segmentasi dan menghilangkan noise pada citra. Setiap citra jenis bunga memiliki 100 data yang ukurannya disamaratakan menjadi sebesar $500 \mathrm{x}$ 500 dengan format .png. Lalu dilakukannya segmentasi untuk mengubah citra jenis bunga RGB (Red, Green, Blue) menjadi citra grayscale terlebih dahulu dengan otsu thresholding [10]. Lalu dilanjutkan dengan operasi morfologi sebagai penghilang noise.

a. Cropping : Cropping ialah proses pemotongan citra di titik tertentu pada area citra. Proses teknik yang digunakan untuk menentukan secara tepat bagian mana dari citra tersebut yang mengandung area objek yang akan diolah. Selain itu proses ini juga dapat mengubah ukuran (resize) citra menjadi lebih 
kecil,untuk mempercepat proses perhitungan .

b. Segmentasi : Segmentasi citra merupakan pemisah antara objek dengan objek lainnya, pada sebuah citra atau antara objek dengan background pada citra [12]. Dalam proses segmentasi tersebut, masing-masing objek pada citra dapat diambil secara individu sehingga dapat digunakan sebagi input bagi proses lain[13]. Terdapat dua macam pada segmentasi, yaitu segmentasi penuh dan segmentasi sebagian .

c. Otsu Thresholding : Otsu thresholding adalah salah satu metode segmentasi yang sederhana dalam teknik segmentasi, sehingga proses yang didapat dengan lebih mudah dalam proses pembagian wilayah homogen berdasarkan kesamaan dalam mengenali objek. Sebelum mengamati hasil segmentasi citra, terlebih dahulu harus melalui proses input citra, agar mudah untuk masuk ke proses selanjutnya. Langkah selanjutnya ialah melakukan penambahan kecerahan pada citra untuk memperbaiki kualitas citra [14]

d. Thresholding : Thresholding merupakan metode yang sangat sederhana dari segmentasi citra lainnya. Dengan inputan citra grayscale, thresholding dapat digunakan untuk membentuk sebuah citra biner. Citra biner adalah citra digital yang setiap pikselnya hanya memiliki dua nilai yaitu warna hitam dan putih yang berdasarkan angka 0 dan 1 .

e. Morfologi : Morfologi digunakan sebagai langkah pertama maupun terakhir dari proses analisis citra. Metode yang digunakan dalam morfologi penelitian ini adalah operasi erosi. Erosi adalah proses membandingkan setiap piksel pada citra masukan dengan nilai elemen struktur sehingga bagian tengah elemen struktur dapat sesuai dengan posisi piksel pada citra yang diproses. [15] operasi morfologi juga berguna untuk menghilangkan noise[16].

3. Ekstrasi Ciri :

a. Warna HSV : HSV digunakan sebagai ekstrasi ciri dengan seleksi warna berdasarkan nilai Hue, Saturation, dan Value. Hue merupakan atribut warna murni. Saturation merupakan intensitas cahaya putih yang mempengaruhi tingkat dominasi warna. Value merupakan perbedaan kecerahan objek . Proses untuk mendapatkan nilai dari setiap warna yang ingin ditampilkan melalui proses perhitungan dengan melakukan konversi ruang warna RGB ke ruang warna HSV [17].

b. Tekstur GLCM : GLCM merupakan sebuah teknik untuk mendapatkan nilai statistik orde ke-2 dengan menghitung probabilitas hubungan kedekatan antara dua buah piksel pada jarak (d) dan sudut $(\theta)$ tertentu. Proses kerja dalam metode GLCM adalah dengan membentuk co-occurrence pada data citra, kemudian menentukan karakteristik fungsional matriks antar piksel [18].

4. K-Nearest Neighbor: KNN (K-Nearest Neighbor) adalah metode klasifikasi objek berdasarkan jarak terdekat dengan objek atau fitur, data yang digunakan paling umum dalam data pembelajaran [19]. Data pelatihan diproyeksikan ke dalam ruang multidimensi, di mana setiap dimensi memiliki fitur pada data. Ruang dibagi menjadi beberapa bagian sesuai dengan klasifikasi data pelatihan . Sebuah titik dalam ruang 
ini ditandai sebagai kategori c, kategori c adalah kategori yang paling umum di antara $\mathrm{k}$ tetangga terdekat titik titik tersebut. Dekat atau jauhnya tetangga biasanya dihitung berdasarkan jarak Euclidean dengan rumus sebagai berikut :

$$
D i j=\sqrt{\sum_{K=1}^{n}(i-j)^{2}}
$$

Keterangan:

Dij : jarak Euclidean antar i dan j.

$\mathrm{i}$ : data pada $\mathrm{x}$ ke-i untuk tahap perhitungan.

$\mathrm{j}$ : data pada y ke-j untuk tahap perhitungan.

\section{HASIL DAN PEMBAHASAN}

Hasil penelitian ini ialah bagaimana cara identifikasi citra jenis bunga dengan menerapkannya ekstrasi ciri warna HSV dan tekstur GLCM algoritma K-Nearest Neighbor (KNN) untuk mengidentifikasi citra jenis bunga ke dalam sepuluh kelas, serta mendapatkan ketepatan akurasi dari hasil evaluasi dalam identifikasi citra jenis bunga masing-masing jenis bunga sebanyak 10 citra, dengan dataset 100 .

1. Pengumpulan Data : Ditahapan ini jenis bunga akan diambil citranya dengan cara mengunjungi web https://www.kaggle.com/ dengan judul Flower Color Image lalu download data publik keseluruhan.
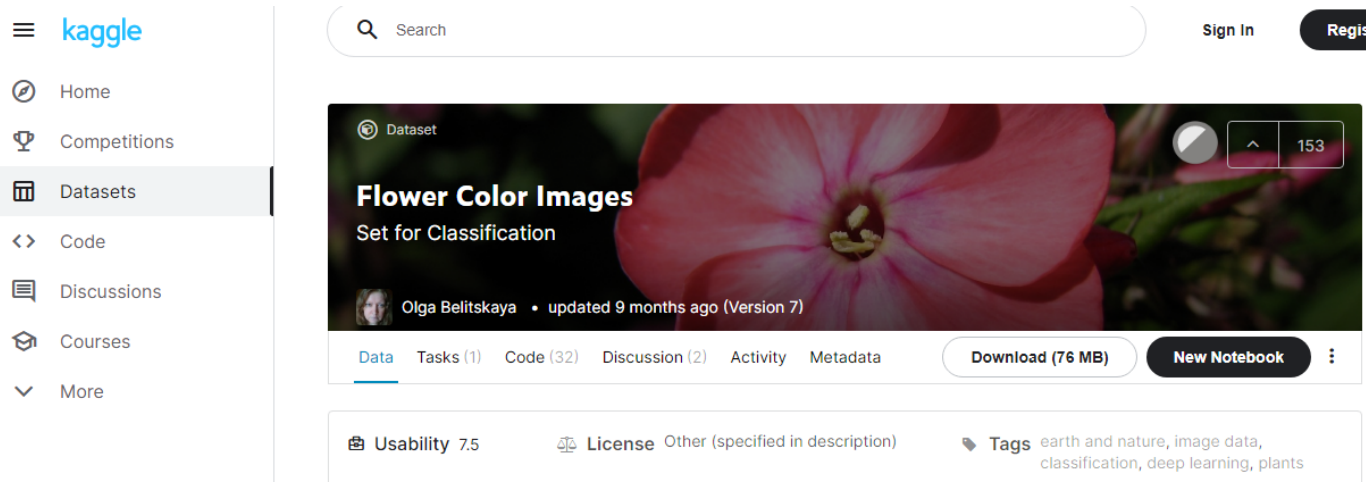

Gambar 3. Halaman Web Kaggle

Berikut adalah hasil data citra yang telah diambil dari web Kaggle

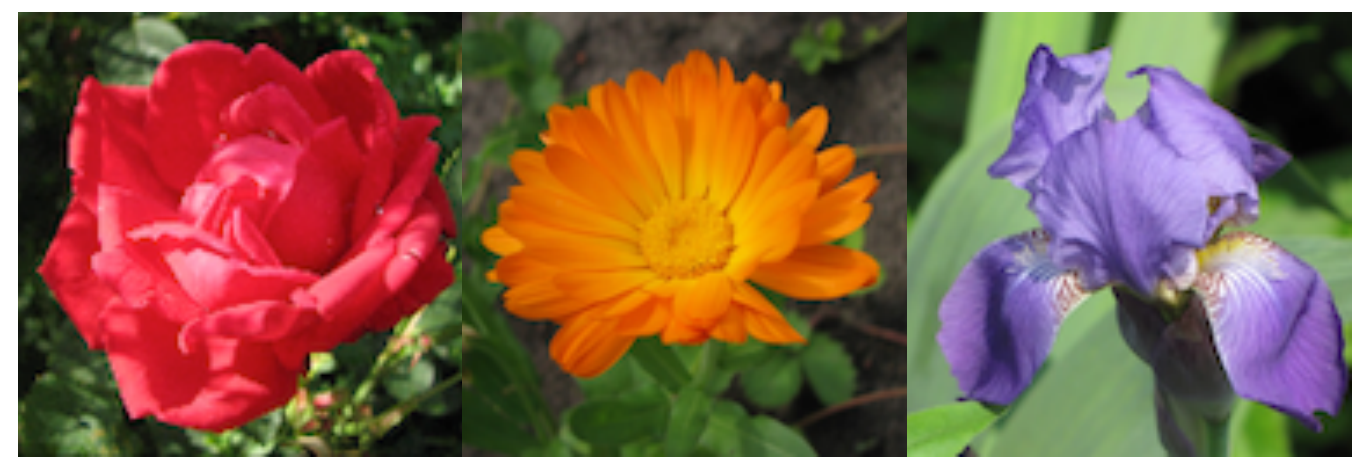


(a)

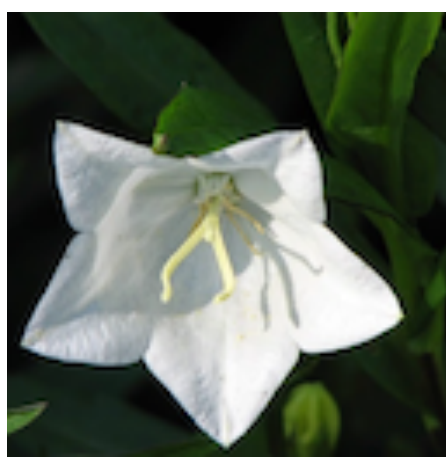

(d) (b)

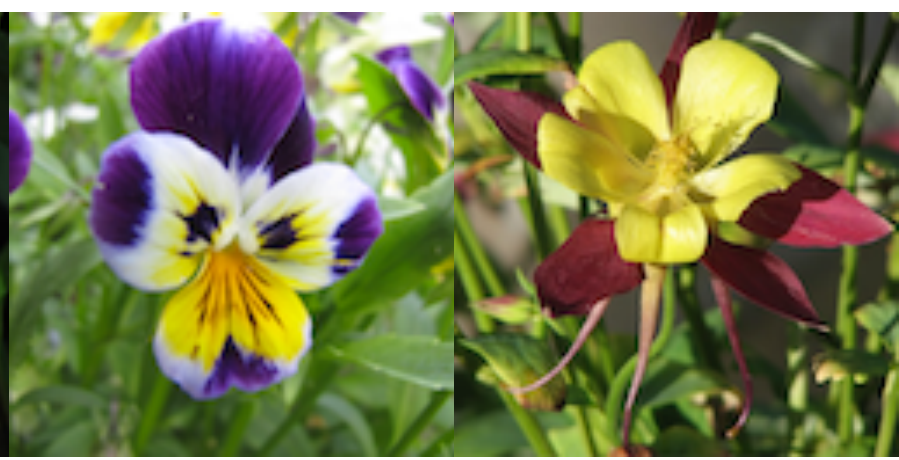

(e)

(f)

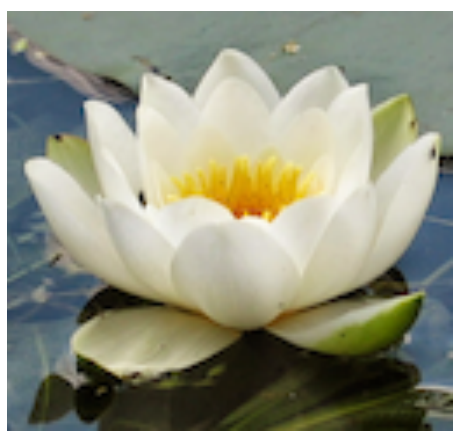

(g)

Gambar 4. (a) Bunga Rose (b) Bunga Calendula (c) Bunga Iris (d) Bunga Bellflower (e) Bunga Viola (f) Bunga Lilium (g) Bunga Water Lily

2. Pre Processing : Pre Processing digunakan untuk mempermudah proses dalam melakukan identifikasi pada citra. Tahap ini terdiri dari cropping, compressing size citra, segmentasi citra dan menghilangkan noise pada citra. Cropping dan compressing size citra dilakukan menggunakan aplikasi pihak ketiga dengan ukuran citra sebesar 500 x 500 pixel serta perbandingan 1:1.

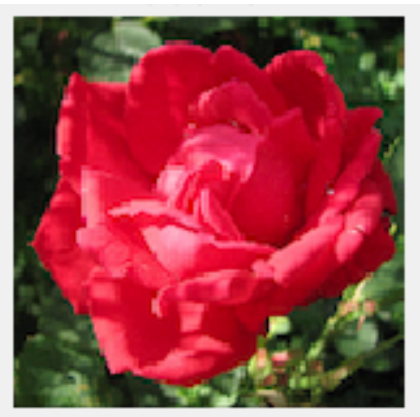

Gambar 5. Citra Asli

Citra yang sudah didapat ini kemudian dikonversi menjadi citra keabuan (grayscale) untuk dilakukannya proses segmentasi. 


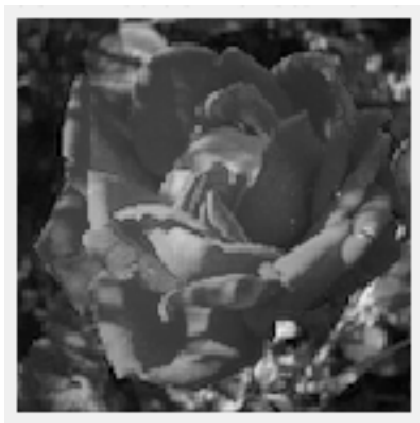

Gambar 6. Citra Grayscale

Lalu segmentasi citra menggunakan software MATLAB dengan otsu thresholding untuk memudahkan proses pengolahan citra ke tahap selanjutnya dengan citra yang telah diubah dari citra RGB menjadi citra keabuan (grayscale), selanjutnya melakukan segmentasi morfologi untuk menghilangkan noise.

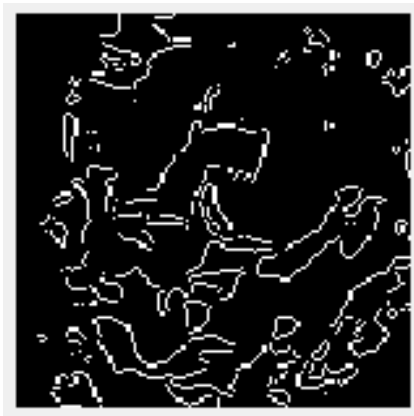

Gambar 7. Citra Biner

3. Ekstrasi Ciri : Pada penelitian ini ekstraksi ciri yang digunakan adalah ekstraksi ciri warna dikarenakan faktor yang mempengaruhi perbedaan pada jenis bunga adalah dari warna. Warna yang meliputi untuk ekstrasi ciri ialah hue, saturation, dan value serta ekstraksi ciri tekstur GLCM yang meliputi contrast, correlation, homogen dan energy. Ekstraksi ciri beragam variasinya, semakin banyak ekstraksi ciri yang relevan dengan citra digunakan maka semakin bagus pula hasil akurasinya. Berikut citra ekstrasi ciri HSV sedangkan untuk ciri GLCM menggunakan citra grayscale.

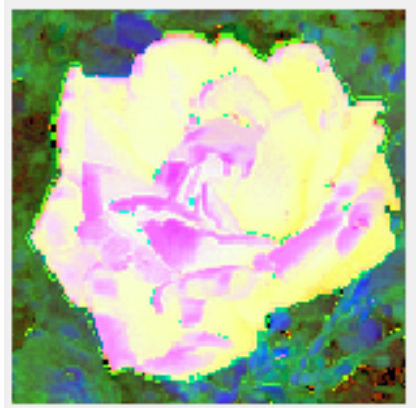

Gambar 8. Citra HSV 
4. K-Nearest Neighbor : Tahap identifikasi data citra jenis bunga menggunakan algoritma $K$-Nearest Neighbor (KNN). Data hasil dari tahap ekstrasi ciri yang telah distandarisasi sebelumnya telah didapatkan, selanjutnya akan dibagi menjadi dua dalam proses pengidentifikasian, yaitu data latih (training) dan data uji (testing). Dalam pembagian data tersebut, diterapkan teknik percentage split dimana terdapat tiga skenario pembagian data. Berikut merupakan detail dari ketiga skenario dari teknik percentage split dan hasil pembagian kelas pada citra jenis bunga:

Tabel 1. Percentage Split

\begin{tabular}{cccc}
\hline No & Split Data & Data Training & Data Testing \\
\hline & & 70 & 21 \\
2 & $70 \%$ dan $30 \%$ & 60 & 28 \\
\hline
\end{tabular}

Tabel 2. Jenis Bunga

\begin{tabular}{cll}
\hline No & Kelas Bunga & \multicolumn{1}{c}{ Jenis Bunga } \\
\hline & & \\
1 & BungaA & Bunga Rose \\
2 & BungaB & Bunga Calendula \\
3 & BungaC & Bunga Iris \\
4 & BungaD & Bunga Bellflower \\
5 & BungaE & Bunga Viola \\
6 & BungaF & Bunga Lilium \\
7 & BungaG & Bunga Water Lily \\
& & \\
\hline
\end{tabular}

Langkah dalam implementasi skenario pembagian data yang telah ditetapkan, dilakukan proses identifikasi menggunakan algoritma $K$-Nearest Neighbor dengan nilai $\mathrm{k}$ yang digunakan yaitu 3,5 dan 7. Berikut merupakan hasil pengujian identifikasi.
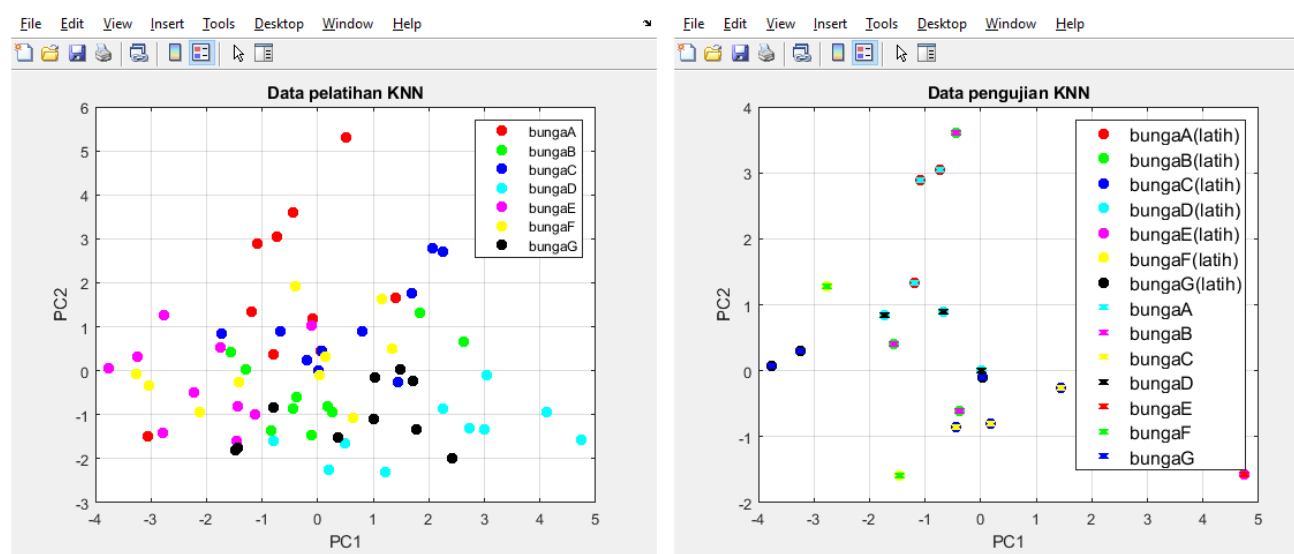

Gambar 9. Visualisasi hasil data pelatihan dan pengujian KNN 


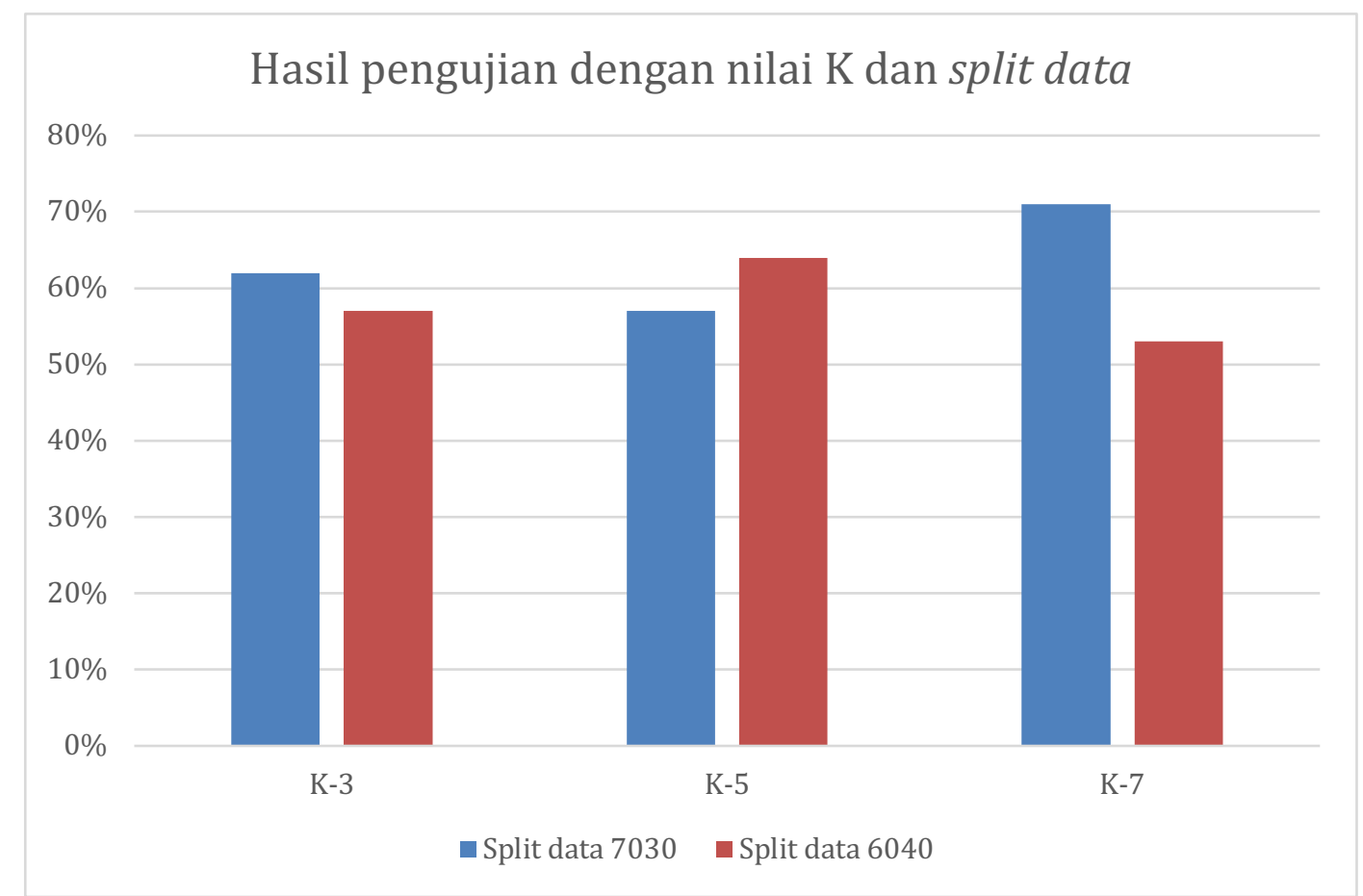

Gambar 10. Hasil Pengujian Dengan nilai K dan Split Data

Pengujian yang pertama ialah pembagian data dengan menggunakan $70 \%$ data latih dan 30\% data uji. Dari seratus citra dengan 10 citra per jenis bunga dibagi menjadi dua data yaitu 70 untuk data latih dan 21 data uji, didapatkan hasil akurasi identifikasi dengan $\mathrm{K}-3=62 \%, \mathrm{~K}-5=57 \%$ dan $\mathrm{K}-7=71 \%$. Sedangkan pada pengujian kedua ialah pembagian data dengan menggunakan $60 \%$ data latih dan $40 \%$ data uji. Dari seratus citra dengan 10 citra per jenis bunga dibagi menjadi dua data yaitu 70 untuk data latih dan 28 data uji, didapatkan hasil akurasi identifikasi dengan $\mathrm{K}-3=57 \%, \mathrm{~K}-5=64 \%$ dan $\mathrm{K}-7=53 \%$.

Pengujian dengan nilai $\mathrm{K}$ dan pembagian data dilakukan untuk mengetahui pengaruh rasio atau persentase tertentu dari jumlah data training dan data testing terhadap tingkat akurasi metode KNN [20]. Setelah pengujian berhasil dilakukan selanjutnya akurasi terbaik dan nilai $\mathrm{K}$ terbaik digunakan untuk identifikasi pada sebuah GUI di MATLAB. Berikut pengujian yang dilakukan dengan GUI.

Didalam GUI terdapat button dengan fungsinya masing, button pertama Input Citra yang berfungsi untuk memasukkan sebuah gambar yang akan diuji, dapat dilihat pada Gambar berikut. 


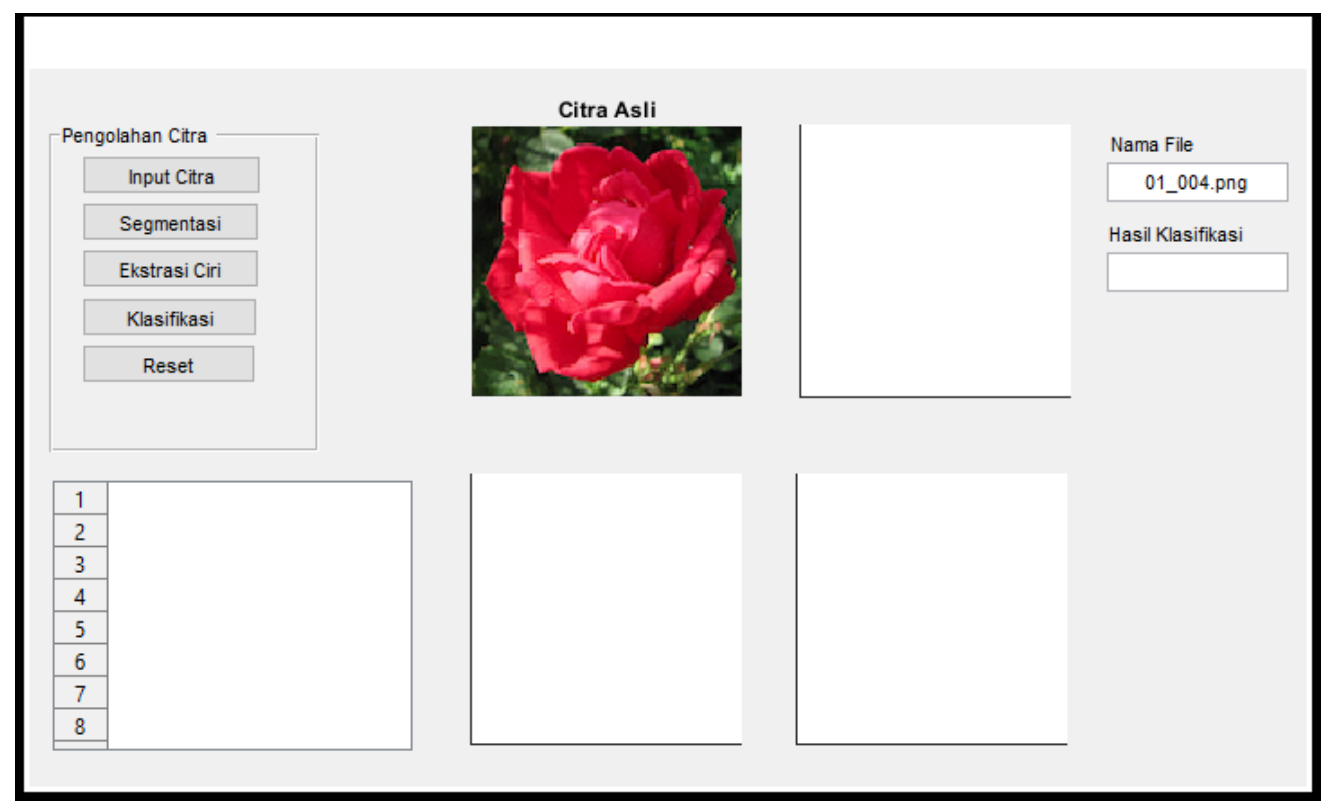

\section{Gambar 11. Input Citra}

Setelah gambar berhasil diinput, gambar akan muncul pada axes 1 atau sebagai citra asli dan disisi kanan terdapat nama file yang telah diinputkan. Selanjutnya ada button segmentasi yang berfungsi untuk melakukan segmentasi terhadap citra dengan morfologi untuk membantu menghilangkan noise, dapat dilihat pada Gambar berikut.

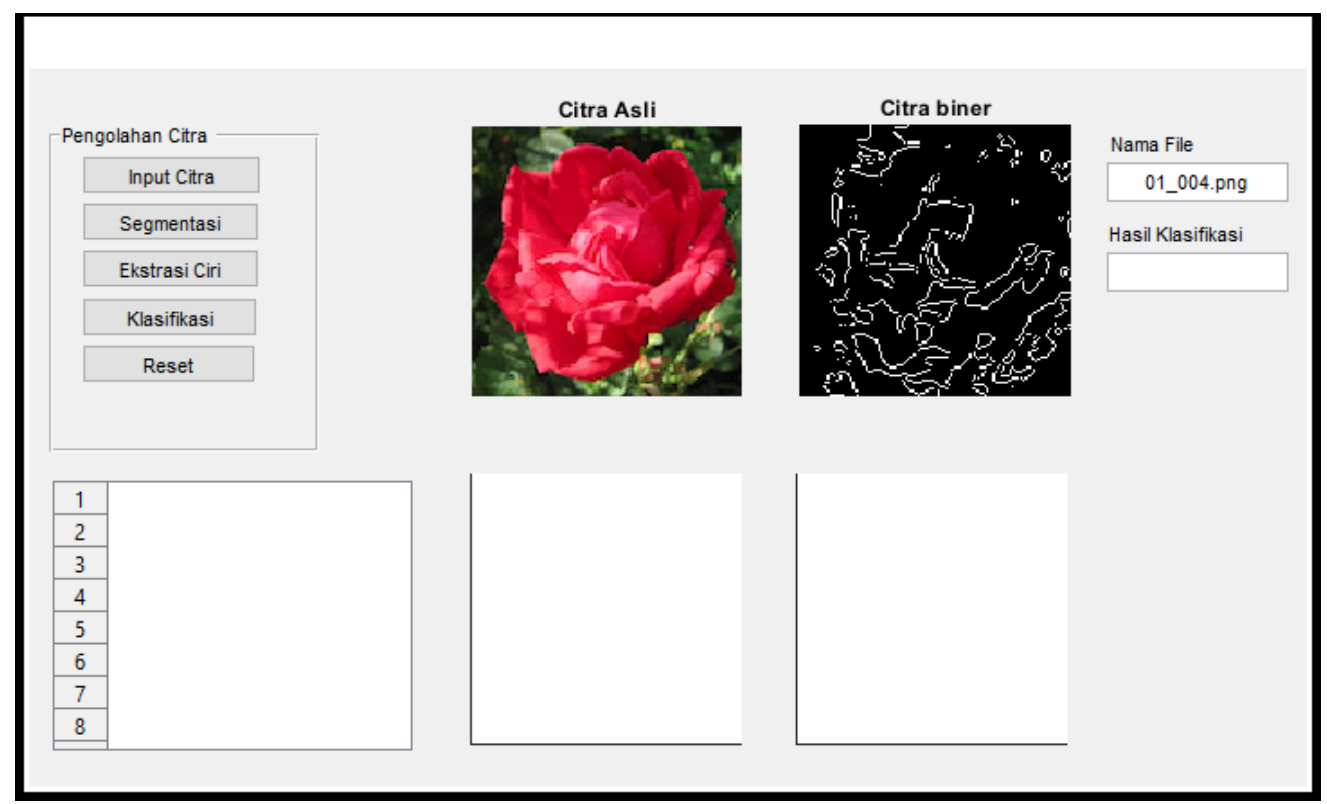

Gambar 12. Segmentasi Citra

Setelah melakukan tahapan preprocessing akan dilakukannya pencarian ekstrasi fitur yang ada pada citra, dapat dilihat pada Gambar berikut. 


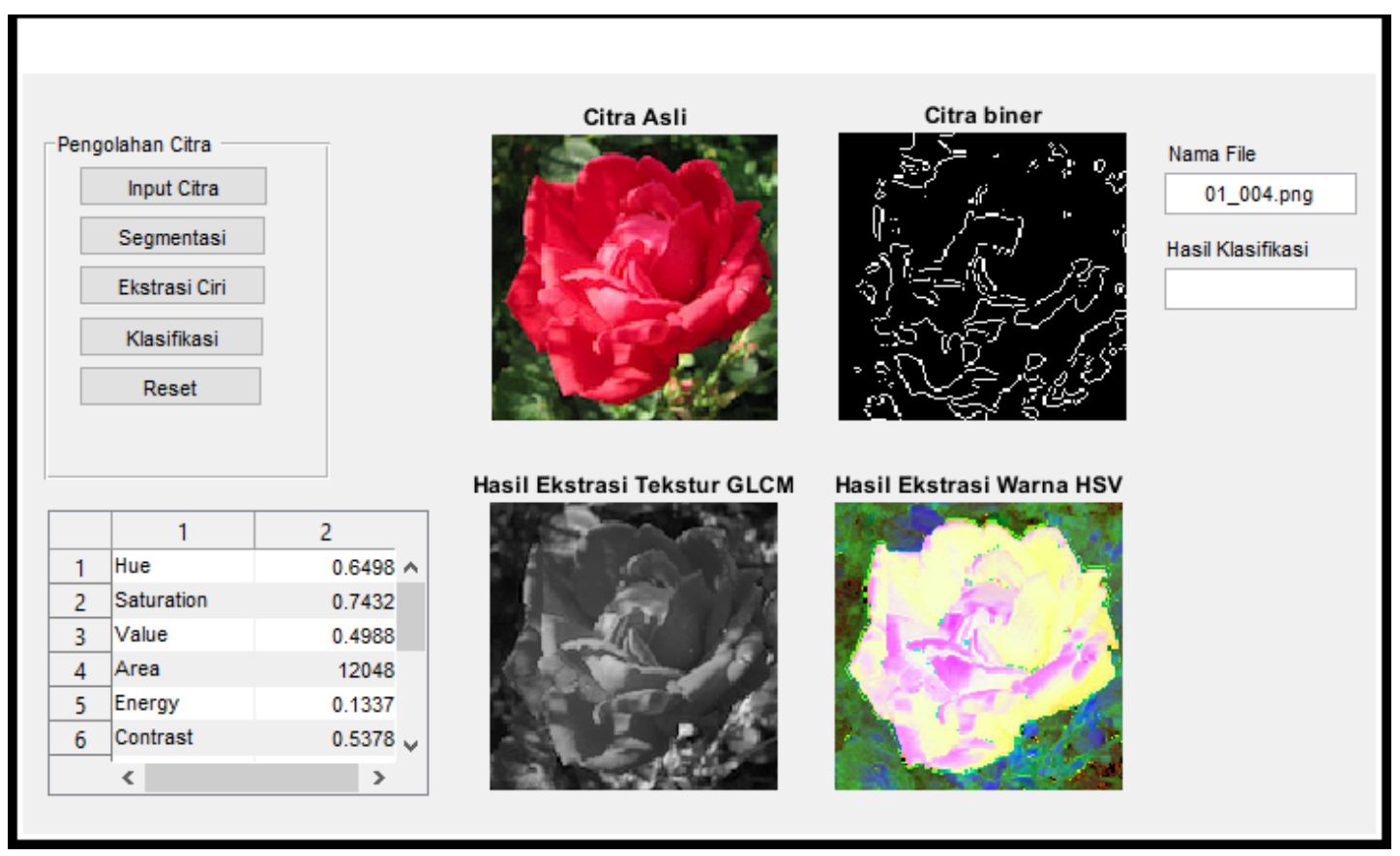

Gambar 13. Ekstrasi Ciri

Dikarenakan menggunakan ciri tekstur GLCM dan ciri warna HSV maka terdapat hasil citra grayscale untuk tekstur dan ciri warna HSV, pada tabel disisi kiri terdapat nilai-nilai ekstrasi fitur dari sebuah citra. Setelah mendapatkan hasil nilai esktrasi pada citra, akan dilakukannya sebuah identifikasi terhadap citra. Dapat dilihat pada Gambar berikut.

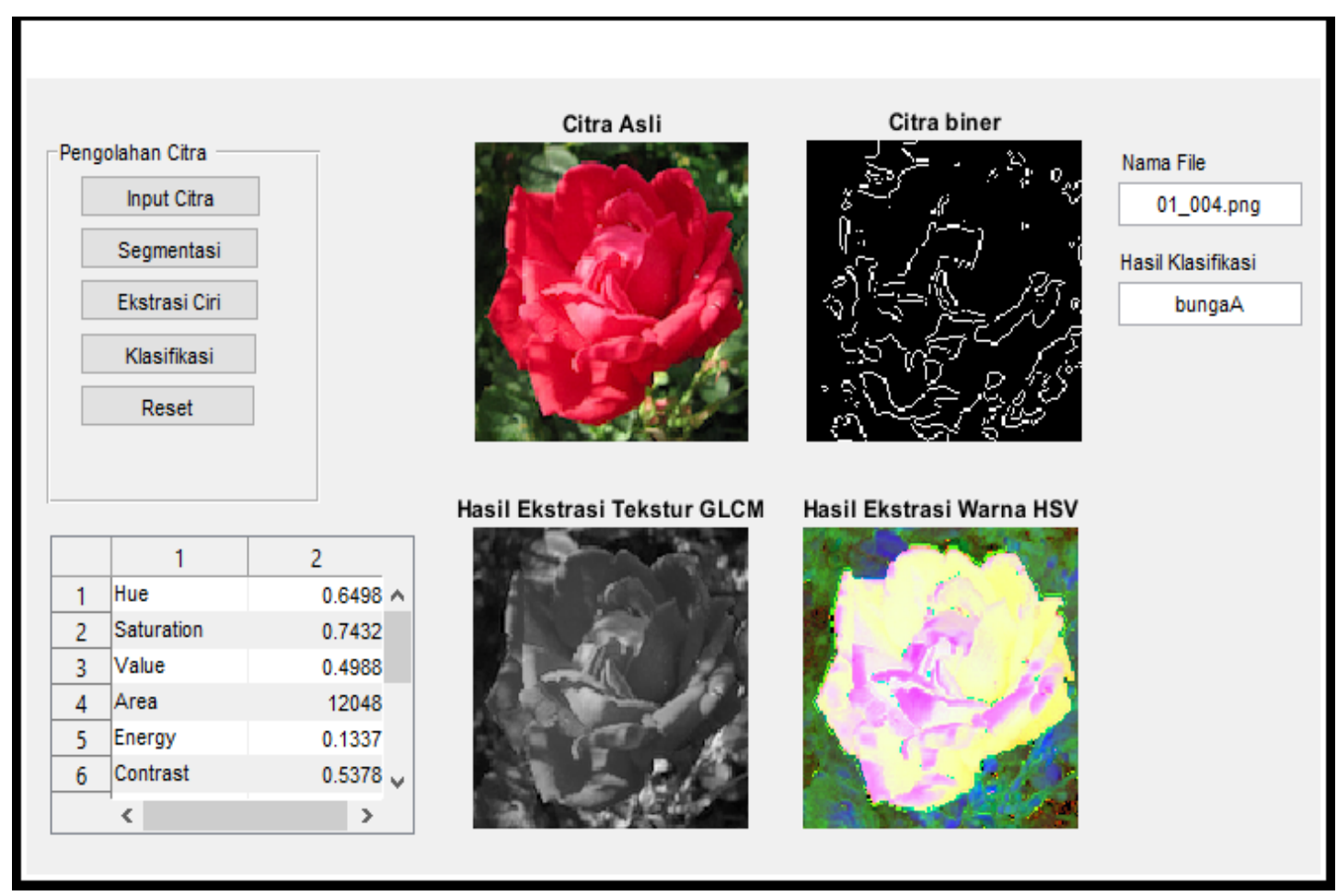

Gambar 14. Hasil Identifikasi

Hasil identifikasi telah didapatkan dan pengujian dengan GUI berhasil 
dilakukan untuk citra jenis bunga Rose teridentifikasi sebagai bungaA dapat dilihat Tabel 2.

Berdasarkan grafik pengujian diatas, terdapat dua skenario pembagian antara data training dan data testing dimana detail pembagiannya telah dijelaskan pada Tabel 1. Pada setiap skenario ini, masing-masing dilakukan percobaan berbagai $\mathrm{K}$ yaitu K-3, K-5 dan K-7. Dari hasil yang telah ditunjukkan pada Gambar 10, dapat diketahui bahwa rasio 70:30 dan K-7 merupakan hasil yang cukup baik dibandingkan dengan pengujian lainnya. Dan pengujian dengan GUI berhasil untuk mengidentifikasi citra jenis bunga sesuai dengan kelasnya

Tabel 3. Hasil Pengujian dengan Nilai K

\begin{tabular}{cccc}
\hline No & Split Data & Nilai K & Akurasi \\
\hline 1 & & K-3 & $62 \%$ \\
2 & \multirow{2}{*}{7030} & K-5 & $57 \%$ \\
3 & & K-7 & $71 \%$ \\
\cline { 2 - 4 } 4 & & K-3 & $57 \%$ \\
5 & 6040 & K-5 & $64 \%$ \\
6 & & K-7 & $53 \%$ \\
\hline
\end{tabular}

\section{KESIMPULAN}

Kesimpulan yang didapatkan pada penelitian Identifikasi Citra Jenis Bunga menggunakan Warna HSV dan Tekstur GLCM ialah identifikasi citra digital jenis bunga menggunakan metode ekstrasi ciri terhadap warna dan tekstur berhasil dilakukan dengan pembagian data 70:30 dan 60:40 serta pengujian pada nilai K-3, K-5, K-7. Mendapatkan akurasi terbaik pada pembagian data 70:30 dengan menggunakan nilai K-7 sebesar $71 \%$, hasil yang didapatkan dirasa kurang dikarenakan data yang didapat sangat terbatas untuk digunakan.

\section{SARAN}

Diharapkan pada penelitian selanjutnya bisa menambahkan jumlah inputan citra jenis bunga agar mendapatkan akurasi yang lebih baik serta penerapan algoritma dan ekstrasi ciri lain yang mendukung untuk identifikasi jenis bunga tersebut.

\section{DAFTAR PUSTAKA}

[1] J. P. Tanjung and B. A. Wijaya, "Facial Recognition Implementation using K-NN and PCA Feature Extraction in Attendance System," Sinkron: jurnal dan penelitian teknik informatika, vol. 5, no. 1, pp. 43-50, 2020.

[2] M. Ramadhani and D. H. Murti, "Klasifikasi Ikan Menggunakan Oriented Fast and Rotated Brief (Orb) Dan K-Nearest Neighbor (Knn)," JUTI J. Ilm. Teknol. Inf, vol. 16, no. 2, p. 115, 2018. 
[3] A. S. Sinaga and E. Marpaung, "Segmentasi Warna HSV Telapak Tangan Untuk Deteksi Bakteri Pada Pendemi Covid 19," Fountain of Informatics Journal, vol. 5, no. 3, pp. 15, 2020.

[4] R. F. Amanullah, A. Pujianto, B. T. Pratama, and K. Kusrini, "Deteksi motif batik menggunakan ekstraksi tekstur dan jaringan syaraf tiruan," CSRID (Computer Science Research and Its Development Journal), vol. 10, no. 2, pp. 69-79, 2021.

[5] K. A. Sugiarta, I. Cholissodin, and E. Santoso, "Optimasi K-Nearest Neighbor Menggunakan Bat Algorithm Untuk Klasifikasi Penyakit Ginjal Kronis," Jurnal Pengembangan Teknologi Informasi dan Ilmu Komputer e-ISSN, vol. 2548, p. 964X, 2020.

[6] C. C. Kusumadewa and S. Supatman, "Identifikasi Citra Daun Teh Menggunakan Metode Histogram untuk Deteksi Dini Serangan Awal Hama Empoasca," JMAI (Jurnal Multimedia \& Artificial Intelligence), vol. 2, no. 1, pp. 27-36, 2018.

[7] Y. Yuhandri, "Perbandingan Metode Cropping Pada Sebuah Citra Untuk Pengambilan Motif Tertentu Pada Kain Songket Sumatera Barat,” Jurnal KomtekInfo, vol. 6, no. 1, pp. 95-105, 2019.

[8] L. Sunarya, A. D. Purbayani, and N. Handayani, "Media Video Promosi Pada Roofpark Cafe \& Restaurant Pucak Bogor Jawa Barat," TMJ (Technomedia Journal) Vol. 5 No. 2 Februari 2021, p. 220, 2021.

[9] I. Handayani, Q. Aini, and C. Y. Kristanti, "Desain Prototype Sales Report Online Menggunakan Konsep Smart Application Pada PT Evergreen Sentosa," TMJ (Technomedia Journal) Vol. 5 No. 1 Agustus 2020, p. 14, 2021.

[10] B. D. Wicaksono and S. Anggraeni, "Perancangan Website Sistem Informasi Transaksi Tagihan Layanan Purna Jual Properti Pada Pollux Properti Indonesia," TMJ (Technomedia Journal) Vol. 5 No. 2 Februari 2021, p. 132, 2021.

[11] I. W. A. Heryanto, M. Artama, M. W. Segara, and I. G. A. Gunadi, "Segmentasi Warna dengan Metode Thresholding," Wahana Matematika dan Sains: Jurnal Matematika, Sains, dan Pembelajarannya, vol. 14, no. 1, pp. 54-64, 2020.

[12] P. Harnis, Y. A. Sari, P. Studi, T. Informatika, F. I. Komputer, and U. Brawijaya, "Segmentasi Citra Kue Tradisional menggunakan Otsu Thresholding pada Ruang Warna CIE LAB," Jurnal pengembangan teknologi informasi dan ilmu komputer, vol. 3, no. 7, pp. 6799-6808, 2019.

[13] N. Sany and M. Kurniawan, "Sistem Informasi Surat Masuk Pada Pengelolaan Rantai Suplai Satuan Kerja Khusus Migas," TMJ (Technomedia Journal) Vol. 5 No. 1 Agustus 2020, p. 27, 2021.

[14] R. Rosyid and M. A. W. Prasetyo, "Robot Peraga 12 Gerakan Pengaturan Lalu Lintas Berbasis Arduino Mega 2560," Technomedia Journal, vol. 5, no. 2, pp. 193-205, 2021.

[15] S. Bhahri and Rachmat, "Transformasi Citra Biner Menggunakan," Jurnal Sistem Informasi dan Teknologi Informasi, vol. 7, no. 2, pp. 195-203, 2018.

[16] H. Sulistiani, A. Yuliani, and F. Hamidy, "Perancangan Sistem Informasi Akuntansi Upah Lembur Karyawan Menggunakan Extreme Programming," Technomedia Journal, vol. 6, no. 01 Agustus, 2021.

[17] P. Rosyani and S. Saprudin, "Deteksi Citra Bunga Menggunakan Analisis Segmentasi Fuzzy C-Means dan Otsu Threshold," MATRIK: Jurnal Manajemen, Teknik Informatika dan Rekayasa Komputer, pp. 27-34, 2020.

[18] M. A. Rahman, N. Hidayat, and A. A. Supianto, "Komparasi Metode Data Mining KNearest Neighbor Dengan Naïve Bayes Untuk Klasifikasi Kualitas Air Bersih (Studi Kasus PDAM Tirta Kencana Kabupaten Jombang)," Jurnal Pengembangan Teknologi Informasi dan Ilmu Komputer e-ISSN, vol. 2548, p. 964X, 2018. 
[19] A. Bode, "K-nearest neighbor dengan feature selection menggunakan backward elimination untuk prediksi harga komoditi kopi arabika," ILKOM Jurnal Ilmiah, vol. 9, no. 2, pp. 188-195, 2017.

[20] M. A. Rahman, N. Hidayat, and A. Afif Supianto, "Komparasi Metode Data Mining KNearest Neighbor Dengan Naïve Bayes Untuk Klasifikasi Kualitas Air Bersih (Studi Kasus PDAM Tirta Kencana Kabupaten Jombang)," Jurnal Pengembangan Teknologi Informasi dan Ilmu Komputer Vol. 2, No. 12, Desember 2018, hlm. 6346-6353 e-ISSN:, vol. 2, no. 12, pp. 925-928, 2018. 